Article

\title{
Effect of Physical Factors on the Growth of Chlorella Vulgaris on Enriched Media Using the Methods of Orthogonal Analysis and Response Surface Methodology
}

\author{
Lile He ${ }^{1}$, Yongcan Chen ${ }^{1, *}$, Xuefei Wu ${ }^{1, *}$, Shu Chen ${ }^{1}$, Jing Liu ${ }^{2}$ and Qiongfang Li ${ }^{3}$ \\ 1 Key Laboratory of Solid Waste Treatment and Resource Recycle of Ministry of Education, \\ Southwest University of Science and Technology, Mianyang 621010, China; swust_he@163.com (L.H.); \\ crickswust@163.com (S.C.) \\ 2 College of Resources and Environment, Southwest University, Chongqing 400715, China; \\ yeelele@aliyun.com \\ 3 School of Life Science and Engineering, Southwest University of Science and Technology, \\ Mianyang 621010, China; liqiongfang@swust.edu.cn \\ * Correspondence: Chenyc@swust.edu.cn (Y.C.); wuxf@swust.edu.cn (X.W.); \\ Fax: +86-081-6608-9051 (Y.C. \& X.W.)
}

Received: 14 November 2019; Accepted: 17 December 2019; Published: 20 December 2019

\begin{abstract}
In addition to chemical factors, physical conditions also play a key role in the growth of microalgae. In this study, solid sediment in rivers was simulated by pure quartz sand with different particle sizes and the physical effects of disturbance rate, solid-liquid ratio and particle size on the growth of Chlorella vulgaris (C. vulgaris) were investigated through orthogonal analysis and response surface methodology (RSM) during co-cultivation of $C$. vulgaris and sediment. The result of ANOVA in orthogonal analysis showed that the effect ability of a single factor on biomass can be ranked as disturbance rate $>$ particle size $>$ solid-liquid ratio, $100 \mathrm{r} / \mathrm{min}$ disturbance rate and 30-40 M particle size are the most significant at the 0.05 level. Furthermore, the specific growth rate can reach $0.25 / \mathrm{d}$ and $0.27 / \mathrm{d}$, respectively. With the growth of $C$. vulgaris, the $\mathrm{pH}$ of the solution reached a maximum of 10.7 in a week. The results from the RSM showed that strong interactions are reflected in the combinations of disturbance rate and solid-liquid ratio, and disturbance rate and particle size. Ramp desirability of the biomass indicates that the optimum levels of the three variables are $105 \mathrm{r} / \mathrm{min}$ disturbance rate, $0.117 \mathrm{~g} / \mathrm{mL}$ solid-liquid ratio and 30-40 M particle size. In this case, the biomass can grow seven times in a week with $0.27 / \mathrm{d}$ specific growth rate and a $\mathrm{pH}$ value of $7-10.4$. This study shows that the growth of $C$. vulgaris can be regulated by changing physical conditions simultaneously, and the optimization of physical conditions can be applied to biomass production, algae prediction and acid water treatment in rivers, lakes and reservoirs.
\end{abstract}

Keywords: factorial designs; response surface methodology; physical conditions; Chlorella vulgaris; Biomass

\section{Introduction}

Chlorella vulgaris (C. vulgaris), a unicellular microalgae, it has been widely used in the fields of eutrophication, heavy metal pollution and biodiesel due to its strong adsorption capacity and fast proliferation [1-6]. C. vulgaris supplementation in medicine can positively affect the health status aspects of growing rabbits [7]. However, the production of biomass plays a decisive role in its applications of effectiveness [8,9]. In rivers, lakes and reservoirs, the effects of many physical conditions (such as hydrodynamic conditions, the particle properties of sediment and solid-liquid 
ratio) on biomass have been studied in addition to chemical conditions (such as $\mathrm{pH}$, dissolved oxygen and lighting).

Hydrodynamics has attracted the interest of many researchers. For example, Yang Song et al. reported that moderate flow velocity and water turbulence increased the algal growth rate and nutrient absorbance in algal cells, respectively [10], and that small-scale turbulence could promote algal nutrient uptake and growth [11]. Yu et al.'s research indicated that the changes in hydrodynamic conditions affect the spatial variation of microalgae [12]. Tian-yu Long et al. established the two-dimensional unsteady ecological dynamic model to analyze the effects of hydrodynamic conditions on algae growth [13]. These studies reflected the effects of water flow rate and disturbance on algal growth at different levels.

The proliferation of microalgae is also influenced by the physical properties of water deposits. On the one hand, nutrient dynamics can be triggered by sediment-water exchanges [14]. Deposited algal cells can affect $\mathrm{N}$ and $\mathrm{P}$ changes at the water-sediment interface [15]. A close relationship is reflected in algae growth and the association between suspended sediment concentration and chlorophyll-a concentration [16]. On the other hand, the ratio of water and sediment increases with the amount of water in the wet season (the situation is just the opposite in dry season) - the fluctuation of water volume represents the change in the solid-liquid ratio in rivers, lakes and reservoirs. Yang et al. revealed the features of water quality dynamics and algal kinetics based on the changes in seasonal water [17]. Therefore, the difference of solid-liquid ratio and flow velocity between the dry and wet season may change the efficiency of microbial utilization of nutrients and chemical interactions (such as $\mathrm{pH}$, and $\mathrm{N} / \mathrm{P}$ ) between microorganisms [18,19].

At present, most research focuses on the chemical factors (such as migration of nutrients, physiological characteristics of cells etc.) in sediment water systems [20-22]. However, there is little research on the effects of pure physical properties (such as solid-liquid ratio and particle size). For example, algae migration ability can be affected by changes in the solid-liquid ratio and sediment particle size to inhibit or promote algae growth. As for the algal growth, the disturbance of the water body, solid-liquid ratio and the particle size of the sediment are lacking in the investigations of single factors and interactions.

In this work, effects of single factor and interaction on $\mathrm{C}$. vulgaris concentration, $\mathrm{pH}$ and specific growth rate are studied by combining the orthogonal method and response surface method (RSM). Specifically, sediment is replaced by quartz sand in order to eliminate the interference of the chemical properties. C. vulgaris is selected as the research object. Disturbance rate, solid-liquid ratio and particle size were chosen as the influencing factors. A comprehensive three-factor, three-level experiment is conducted with the co-cultivation of $C$. vulgaris and sediment. Data extracted from this comprehensive experiment is used for the L9-3-3 orthogonal design and the Box-Behnken design (BBD) model analysis of RSM, respectively. In addition, the physical conditions of algae growth are optimized, which can be applied to biomass production and algae prediction in rivers, lakes and reservoirs.

\section{Experimental Methods}

\subsection{The Process of Comprehensive Experiment}

The experiment factors and levels are set to A: disturbance rate ( $50 \mathrm{r} / \mathrm{min}, 100 \mathrm{r} / \mathrm{min}$ and $150 \mathrm{r} / \mathrm{min})$, B: solid-liquid ratio $(0.025 \mathrm{~g} / \mathrm{mL}, 0.125 \mathrm{~g} / \mathrm{mL}$ and $0.25 \mathrm{~g} / \mathrm{mL})$ respectively. The comprehensive experiment with three factors and three levels $\left(3^{3}=27\right.$ groups $)$ is divided into three batches according to disturbance rates; each batch contains experimental (three levels of particle size and solid-liquid ratios) and blank groups (no quartz sand) with parallel samples.

The operational flow of each batch is as follows: twenty $250 \mathrm{~mL}$ Erlenmeyer flasks are prepared, including 18 experimental groups and 2 blank groups. Sediment is weighed ( $5 \mathrm{~g}, 25 \mathrm{~g}$ and $50 \mathrm{~g}$ ) in the experimental groups with $200 \mathrm{~mL}$ C. vulgaris suspension (initial biomass is diluted to $1 \times 10^{6} \mathrm{cells} / \mathrm{mL}$ with BG-11 medium). So, cultures featuring a solid-liquid ratio of $0.025 \mathrm{~g} / \mathrm{mL}, 0.125 \mathrm{~g} / \mathrm{mL}$ and $0.25 \mathrm{~g} / \mathrm{mL}$, 
respectively, are incubated in a constant temperature light incubator for one week with the biomass, $\mathrm{pH}$ and specific growth rate of each culture measured daily.

\subsection{Experimental Sediments}

Pretreated quartz sand was used as a sediment in this study in order to avoid interference from organic matter, microbial organisms or other elements (N, P or heavy metal ions). Quartz sand is screened by sieves for different particle sizes of 5-7 mesh, 10-20 mesh and 30-40 mesh, and stored after $1 \mathrm{M} \mathrm{HCl}$ cleaning and high temperature sterilization $\left(130^{\circ} \mathrm{C}\right)$.

\subsection{The Cultivation of C. Vulgaris}

C. vulgaris strain (serial number: FACHB-8) is obtained from the Freshwater Algae Culture Collection at the Institute of Hydrobiology (FACHB-Collection, FACHB, Wuhan, China), China. BG-11 standard medium is used for the culture of $C$. vulgaris. The standard composition is as follows: $\mathrm{NaNO}_{3}(1500 \mathrm{mg} / \mathrm{L}) ; \mathrm{K}_{2} \mathrm{HPO}_{4}(40 \mathrm{mg} / \mathrm{L}) ; \mathrm{MgSO}_{4} \cdot 7 \mathrm{H}_{2} \mathrm{O}(75 \mathrm{mg} / \mathrm{L}) ; \mathrm{CaCl}_{2} \cdot 2 \mathrm{H}_{2} \mathrm{O}(36 \mathrm{mg} / \mathrm{L}) ;$ citric acid $(6 \mathrm{mg} / \mathrm{L})$; ferric ammonium citrate $(6 \mathrm{mg} / \mathrm{L})$; disodium EDTA $(1 \mathrm{mg} / \mathrm{L}) ; \mathrm{Na}_{2} \mathrm{CO}_{3}(20 \mathrm{mg} / \mathrm{L}) ; \mathrm{A}_{5}(1 \mathrm{ml} / \mathrm{L})$. The composition of the $\mathrm{A}_{5}$ metal solution is as follows: $\mathrm{H}_{3} \mathrm{BO}_{3}(2.86 \mathrm{~g} / \mathrm{L}) ; \mathrm{MnCl}_{2} \cdot 4 \mathrm{H}_{2} \mathrm{O}(1.86 \mathrm{~g} / \mathrm{L})$; $\mathrm{ZnSO}_{4} \cdot 7 \mathrm{H}_{2} \mathrm{O}(0.22 \mathrm{~g} / \mathrm{L}) ; \mathrm{Na}_{2} \mathrm{MoO}_{4} \cdot 2 \mathrm{H}_{2} \mathrm{O}(0.39 \mathrm{~g} / \mathrm{L}) ; \mathrm{CuSO}_{4} \cdot 5 \mathrm{H}_{2} \mathrm{O}(0.08 \mathrm{~g} / \mathrm{L}) ; \mathrm{Co}\left(\mathrm{NO}_{3}\right)_{2} \cdot 6 \mathrm{H}_{2} \mathrm{O}(0.05 \mathrm{~g} / \mathrm{L})$.

The initial $\mathrm{pH}$ is adjusted to 7 with $1 \mathrm{~mol} / \mathrm{L} \mathrm{NaOH}$ and $\mathrm{HCl}$. The conical flask is placed in a constant temperature light incubator at $25^{\circ} \mathrm{C}$, and a warm light of 5000 lux is continuously operated with a day/night cycle of $12 \mathrm{~h} / 12 \mathrm{~h}$ after determining the initial biomass. The standard curve of biomass was produced by a mounted bio-optical microscope $(40 \times)$ and chlorophyll fluorometer $(680 \mathrm{~nm})$. The linear relationship is expressed as follows:

$$
\text { Biomass }(\text { cells } / \mathrm{mL})=4.17 \times 10^{5} \times \mathrm{OD}_{680},
$$

The specific growth rate of $C$. vulgaris is calculated through biomass and time, as follows:

$$
\text { Specific growth rate }(\%)=100 \times\left(\frac{\ln X_{2}-\ln X_{1}}{T_{2}-T_{1}}\right)
$$

where $\mathrm{X}$ represents biomass concentrations at day $\mathrm{T}$, and 1 and 2 represents the initial point and end point, respectively [2].

\subsection{Instruments and Tests}

Constant temperature light incubator (HT Multitron, Infors, Zurich, Switzerland); mounted bio-optical microscope (DM2000, Leica, Berlin, Germany); chlorophyll fluorometer (Aquafluor 805186, Turner, Sunnyvale, USA); centrifuge (TGL-16G, Feige, Shanghai, China); high temperature autoclave (MLS-3780, Sanyo, Osaka, Japan); UV spectrophotometer (Evolution 300, Thermo scientific instrument, Waltham, USA); pH meter (PB-21, Sartorius, Göttingen, Germany).

\subsection{Design of Orthogonal Experiment}

All orthogonal experimental data is extracted from the comprehensive experiment of three factors and three levels ( 9 sets) of classical distribution data for the analysis of single factor impact. The array and code of classical distribution in the orthogonal columns is adopted by the orthogonal design assistant software (second version).

\subsection{Establishment of RSM}

Box-Behnken design (BBD) with Design-Expert software (Stat-Ease, Minneapolis, Minnesota, USA) is employed to analyze interactions and optimum conditions. As a standard RSM, BBD is performed with a total of 17 experiments. All data is extracted from the comprehensive experiment of three factors and three levels. Three independent variables in this experiment, i.e., disturbance 
rate $(50 \mathrm{r} / \mathrm{min}, 100 \mathrm{r} / \mathrm{min}$ and $150 \mathrm{r} / \mathrm{min})$, solid-liquid ratio $(0.025 \mathrm{~g} / \mathrm{mL}, 0.125 \mathrm{~g} / \mathrm{mL}$ and $0.25 \mathrm{~g} / \mathrm{mL})$, and particle size (5-7 mesh, 10-20 mesh and 30-40 mesh) are evaluated to determine the response of biomass and $\mathrm{pH}$. The experimental data are fitted using the following second-order polynomial equation in Equation (3):

$$
y_{i}=\beta_{0}+\sum \beta_{i} x_{i}+\sum \beta_{i i} x_{i}^{2}+\sum \beta_{i j} x_{i} x_{j}
$$

\section{Results and Discussion}

\subsection{The Results of Biomass and $\mathrm{pH}$ in the Comprehensive Experiment}

A comprehensive three factor and three level experiment was completed (with a total of 27 groups). The change of biomass is shown in Figure 1. Here, a shortcoming of Figure 1 is mentioned as the internal data is not well differentiated in order to compare the vertical axes of the data on a uniform scale.

Many studies have shown that hydrodynamics have a significant effect on the growth and development of microalgae [12,23]. Therefore, the disturbance rate of the water flow is listed in the form of a longitudinal comparison.

The horizontal comparison from Figure 1 (Groups a,d,g; b,e,h; and c,f,i) clearly demonstrates that the disturbance rate has a significant effect on the maximum biomass of algae, and the change in results can be distinguished by the particle size of the sediment. The effect of the solid-liquid ratio on biomass is also obvious in Figure $1 \mathrm{~b}, \mathrm{~g}, \mathrm{~h}$. The maximum biomass has significant differences, although the curve spacing is not clear under the turbulence rate of $100 \mathrm{r} / \mathrm{min}$. Therefore, multi-factor interaction needs to be considered. It can be determined from Figure 1 that the disturbance rate and particle size have a significant effect on the growth of $C$. vulgaris, while Figure $1 \mathrm{~b}, \mathrm{~g}, \mathrm{~h}$ implies the action of the solid-liquid ratio. The effect of single factor and multivariate interactions on biomass will be explored in the orthogonal analysis and RSM, respectively.

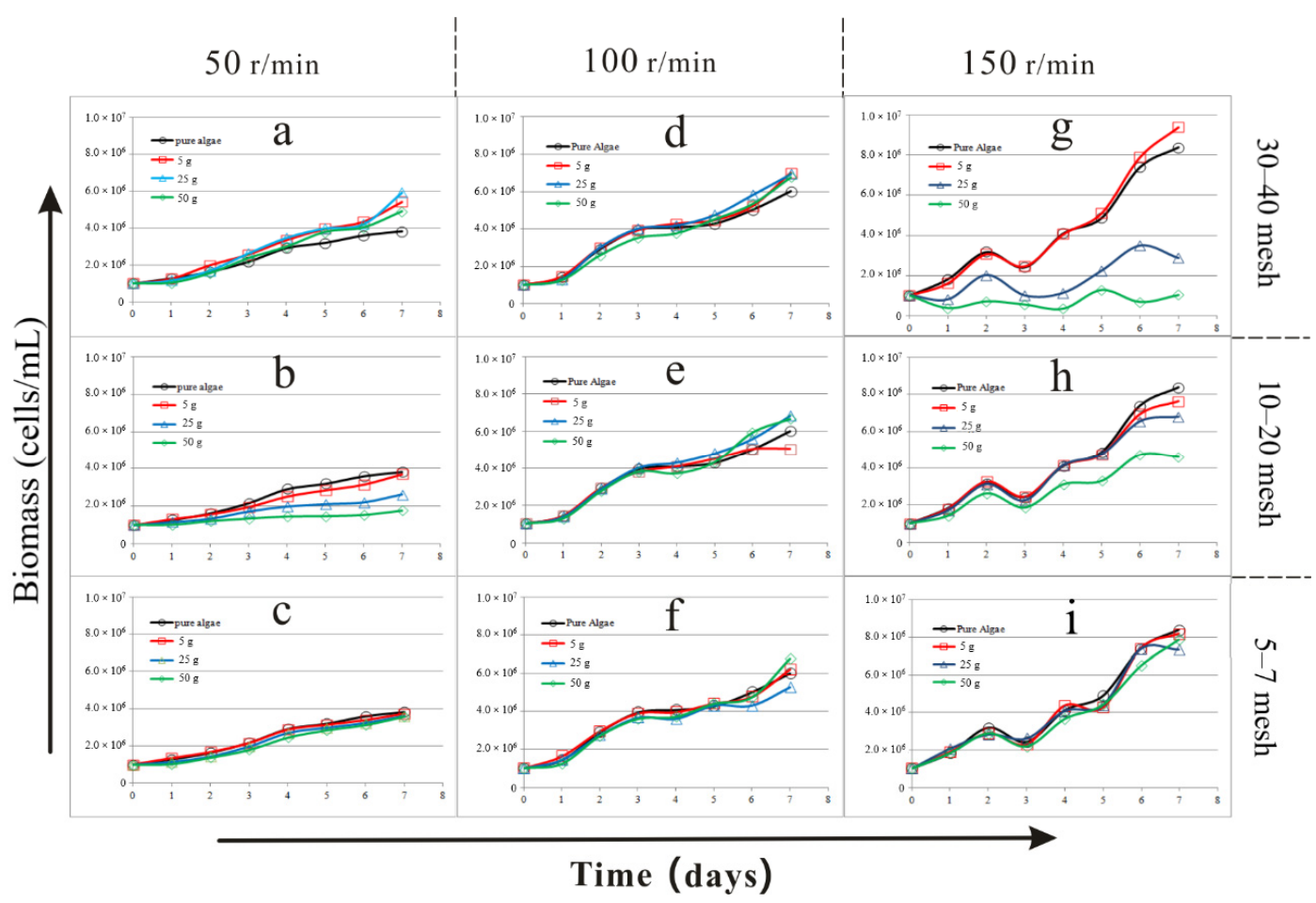

Figure 1. The change of biomass in orthogonal comprehensive experiments (three levels of disturbance rate are used as columns, three levels of particle size are used as rows, and three levels of solid-liquid ratio are used as intrinsic changes). Each subfigure (a-i) contains the same three levels of solid-liquid ratio. Groups a-c; d-f; and g-i according to different disturbance rate. Groups a,d,g; b,e,h; and c,f,i according to different meshes. 
The value of solution $\mathrm{pH}$ is considered to be an important assessment factor for the interactions of the water body and the growth of microalgae [20,24,25]. C. vulgaris facilitates the treatment of acidic water during the metabolic process of proliferation, as metabolites increase the $\mathrm{pH}$ of the water. However, the optimum range of $\mathrm{pH}$ for the growth of $C$. vulgaris is $5-9[20,26]$. Therefore, investigating the effects of physical factors on $\mathrm{pH}$ becomes especially important in this process.

The change of solution $\mathrm{pH}$ in the comprehensive experiment is presented in Figure 2. A good discrimination is presented in a lateral comparison (Groups a,d,g; b,e,h; c,f,i in Figure 2), suggesting that $\mathrm{pH}$ is more sensitive to sediment particle size. In addition, the $\mathrm{pH}$ of the experimental group of the same particle size becomes unstable with the increase of disturbance rate and solid-liquid ratio when the initial $\mathrm{pH}$ is 7 , which implies the influence of the interaction between physical factors. Effect of single factor and multivariate interaction on $\mathrm{pH}$ will be explored in the orthogonal analysis and RSM, respectively.

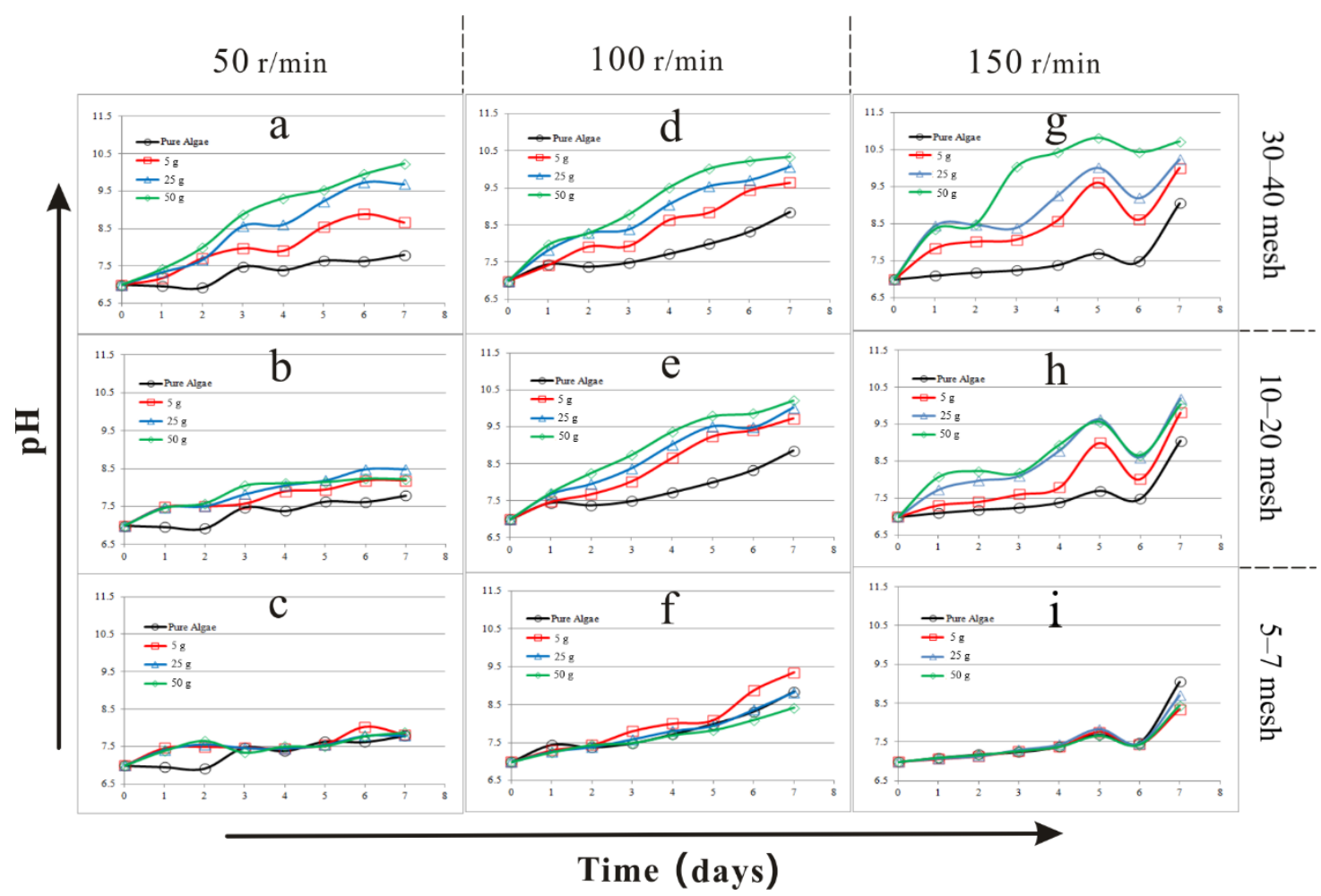

Figure 2. The change of biomass in orthogonal comprehensive experiments (three levels of disturbance rate are used as columns, three levels of particle size are used as rows, and three levels of solid-liquid ratio are used as intrinsic changes). Each subfigure (a-i) contains the same three levels of solid-liquid ratio. Groups a-c; d-f; and g-i according to different disturbance rate. Groups a,d,g; b,e,h; and c,f,i according to different meshes.

\subsection{The Classical Orthogonal Distribution}

Orthogonal analysis is considered to be very effective for examining factor effects [27]. In order to investigate the effect of individual physical factors on biomass, $\mathrm{pH}$ and specific growth rate, the classical orthogonal distribution is adopted. Nine experimental groups with three factors and three levels of classical orthogonal distribution (L9-3-3) are correspondingly extracted from the comprehensive experiment.

\subsection{Range Analysis of the Orthogonal Experiment}

The range analysis is widely used due to operational advantages; it determines the ability of factors to influence the target. According to the L9-3-3 matrix, the $K_{i}$ (average value of the experiment 
index) and $\mathrm{R}$ (range) of each factor is listed in Table $1 . \mathrm{K}_{\mathrm{i}}$ indicates the ability of each factor at the $\mathrm{i}$ level. $\mathrm{R}$ indicates the strength of each factor to the target. A larger Ki or R means that the impact ability factor is stronger. We judged the ability of three physical factors to influence the growth of $C$. vulgaris according to the $\mathrm{K}_{\mathrm{i}}$ and $\mathrm{R}$ value of each index.

By comparing the $\mathrm{Ki}$, we got $\mathrm{K}_{\mathrm{A} 2}>\mathrm{K}_{\mathrm{A} 3}>\mathrm{K}_{\mathrm{A} 1}, \mathrm{~K}_{\mathrm{B} 2}>\mathrm{K}_{\mathrm{B} 1}>\mathrm{K}_{\mathrm{B} 3}, \mathrm{~K}_{\mathrm{C} 3}>\mathrm{K}_{\mathrm{C} 1}>\mathrm{K}_{\mathrm{C} 2}$ for biomass. This shows that the optimal levels of disturbance rate, solid-liquid ratio and particle size for biomass are $100 \mathrm{r} / \mathrm{min}, 0.125 \mathrm{~g} / \mathrm{mL}$ and $30-40 \mathrm{M}$, respectively. For $\mathrm{pH}$, we found $\mathrm{K}_{\mathrm{A} 2}>\mathrm{K}_{\mathrm{A} 3}>\mathrm{K}_{\mathrm{A} 1}, \mathrm{~K}_{\mathrm{B} 3}>\mathrm{K}_{\mathrm{B} 1}$ $>\mathrm{K}_{\mathrm{B} 2}, \mathrm{~K}_{\mathrm{C} 3}>\mathrm{K}_{\mathrm{C} 2}>\mathrm{K}_{\mathrm{C} 1}$-the order reflects the strongest levels of $\mathrm{pH}$ at $100 \mathrm{r} / \mathrm{min}, 0.25 \mathrm{~g} / \mathrm{mL}$ and 30-40 M. We saw $\mathrm{K}_{\mathrm{A} 3}>\mathrm{K}_{\mathrm{A} 2}>\mathrm{K}_{\mathrm{A} 1}, \mathrm{~K}_{\mathrm{B} 1}>\mathrm{K}_{\mathrm{B} 3}>\mathrm{K}_{\mathrm{B} 2}, \mathrm{~K}_{\mathrm{C} 3}>\mathrm{K}_{\mathrm{C} 2}>\mathrm{K}_{\mathrm{C} 1}$ for the specific growth rate; the optimum values are stated to be $150 \mathrm{r} / \mathrm{min}, 0.025 \mathrm{~g} / \mathrm{mL}$ and $30-40 \mathrm{M}$.

By comparing the $R$, we got $R_{A}>R_{C}>R_{B}$ for biomass, $R_{A}>R_{B}>R_{C}$ for $p H$, and $R_{A}>R_{C}>R_{B}$ for the specific growth rate. This illustrated that the effect of disturbance rate on biomass and the specific growth rate is most sensitive compared to other factors, followed by sediment particle size. Disturbance rate has the greatest impact on the solution $\mathrm{pH}$, with solid-liquid ratio in second place.

Table 1. Range analysis from orthogonal experiments.

\begin{tabular}{|c|c|c|c|c|c|c|c|c|c|}
\hline \multirow{2}{*}{ Factors } & \multicolumn{3}{|c|}{ Biomass $\left(1.0 \times 10^{7}\right.$ cells $\left./ \mathrm{mL}\right)$} & \multicolumn{3}{|c|}{$\mathrm{pH}$} & \multicolumn{3}{|c|}{ Specific Growth Rate $\left(\mathrm{d}^{-1}\right)$} \\
\hline & $\mathbf{A}$ & B & $\mathrm{C}$ & $\mathbf{A}$ & B & $\mathrm{C}$ & $\mathbf{A}$ & B & $\mathrm{C}$ \\
\hline $\mathrm{K}_{1}$ & 3.74 & 5.62 & 6.12 & 8.845 & 9.178 & 8.62 & 0.185 & 0.245 & 0.227 \\
\hline $\mathrm{K}_{2}$ & 6.31 & 5.64 & 3.58 & 9.712 & 9.087 & 9.413 & 0.258 & 0.223 & 0.242 \\
\hline $\mathrm{K}_{3}$ & 6.14 & 4.92 & 6.48 & 9.577 & 9.868 & 10.1 & 0.273 & 0.239 & 0.247 \\
\hline Rank & & $\begin{array}{l}\mathrm{K}_{\mathrm{A} 3} \\
\mathrm{~K}_{\mathrm{B} 1} \\
\mathrm{~K}_{\mathrm{C} 1}\end{array}$ & & $\begin{array}{c}\mathrm{K}_{\mathrm{A}} \\
\mathrm{K}_{\mathrm{B}} \\
\mathrm{K}_{\mathrm{B}}\end{array}$ & $\begin{array}{l}>K_{\mathrm{A} 3}> \\
>\mathrm{K}_{\mathrm{B} 1}> \\
>\mathrm{K}_{\mathrm{B} 1}>\end{array}$ & $\begin{array}{l}\mathrm{A} 1 \\
\mathrm{~B} 2 \\
\mathrm{~B} 2\end{array}$ & $\begin{array}{l}\mathrm{K} \\
\mathrm{K} \\
\mathrm{K}\end{array}$ & $\begin{array}{r}>K_{\mathrm{B} 1}> \\
>\mathrm{K}_{\mathrm{B} 3}> \\
>\mathrm{K}_{\mathrm{C} 2}>\end{array}$ & \\
\hline $\begin{array}{l}\text { Range (R) } \\
\text { Ring }\end{array}$ & 2.90 & $\begin{array}{c}0.72 \\
>C>\end{array}$ & 2.57 & 0.867 & $\begin{array}{c}0.781 \\
>B>\end{array}$ & 1.48 & 0.088 & $A>C>B$ & 0.02 \\
\hline
\end{tabular}

\subsection{Factor Effects and Variance (ANOVA) of the Orthogonal Experiment}

The trend chart of the single factor for biomass is shown in Figure 3. It clearly shows that the two most significant factors are the disturbance rate and the solid-liquid ratio. At the same time, there is a clear difference between the two. The influence of the former is gradually increasing, and the highest effect is exhibited at $100 \mathrm{r} / \mathrm{min}$, which is also in line with the results of the analysis of variance. The latter is V-shaped as the negative effect becomes stronger when the solid-liquid ratio is $0.125 \mathrm{~g} / \mathrm{mL}$. In contrast, the effect of particle size of the sediment is stable. However, the negative effect trend is obvious when the particle size is greater than 10-20 M, which may be due to the retardation being enhanced by the smaller particle size during the migration of the microalgae.

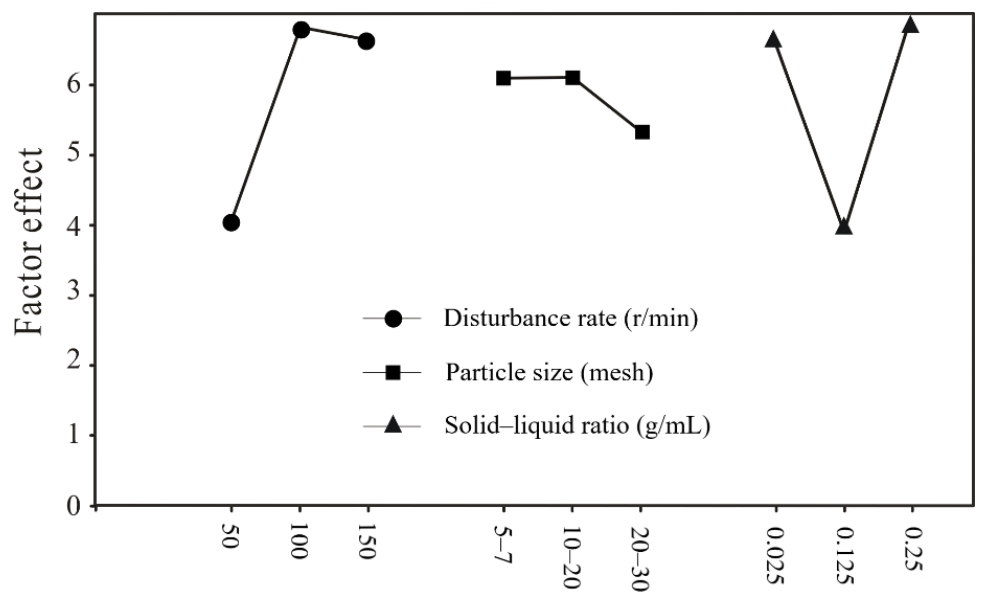

Figure 3. Trend chart for single factor effects on biomass. 
The significance of a single factor can be evaluated by analysis of variance (ANOVA) with an F-test. The ANOVA of various factors for biomass is listed in Table 2. It clearly shows the significance of $\mathrm{A}$ and $\mathrm{C}$ at the 0.05 level. In other words, the effect of the disturbance rate and the particle size of the sediment on the biomass production of $C$. vulgaris are very significant. The results are consistent with the range analysis, and the F-test guarantees the accuracy of the analysis.

Table 2. Analysis of variance (ANOVA) of three factors affecting biomass.

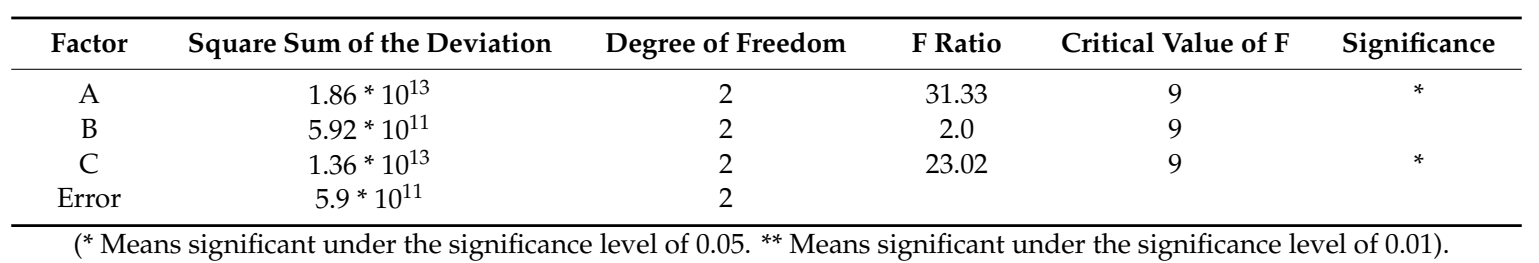

\subsection{Box-Behnken Design of RSM}

Experimental data is strictly assigned according to BBD-17 groups of experiments from the comprehensive three factor and three level experiments are extracted for BBD analysis. Additional experiments are supplemented under the same level of $A B C$ when the number of experimental groups is more than two, such as the ABC levels of $100 \mathrm{r} / \mathrm{min}, 0.125 \mathrm{~g} / \mathrm{mL}$ and 20-30 M. The design matrix and the output responses for biomass and $\mathrm{pH}$ are shown in Table 3.

Table 3. Box-Behnken experimental design (BBD) and experimental results in the response surface methodology (RSM).

\begin{tabular}{|c|c|c|c|c|c|}
\hline & Factor 1 & Factor 2 & Factor 3 & Response 1 & Response 2 \\
\hline Run & $\begin{array}{l}\text { A: Disturbance } \\
\text { Rate (r/min) }\end{array}$ & $\begin{array}{l}\text { B: Solid-Liquid } \\
\text { Ratio (g/mL) }\end{array}$ & $\begin{array}{c}\text { C: Particle } \\
\text { Size (mesh) }\end{array}$ & $\begin{array}{c}\text { Biomass }\left(1 \times 10^{6}\right. \\
\text { cell } / \mathrm{mL})\end{array}$ & $\mathrm{pH}$ \\
\hline 1 & 150 & 0.25 & $20-30$ & 4.63 & 10.03 \\
\hline 2 & 150 & 0.125 & $30-40$ & 2.87563 & 10.24 \\
\hline 3 & 50 & 0.025 & $20-30$ & 3.70375 & 8.18 \\
\hline 4 & 50 & 0.125 & $5-7$ & 3.6025 & 7.79 \\
\hline 5 & 100 & 0.125 & $20-30$ & 6.665 & 9.94 \\
\hline 6 & 50 & 0.25 & $20-30$ & 1.774 & 8.22 \\
\hline 7 & 100 & 0.125 & $20-30$ & 7.0025 & 10.09 \\
\hline 8 & 50 & 0.125 & $30-40$ & 5.93563 & 9.69 \\
\hline 9 & 100 & 0.25 & $5-7$ & 6.77375 & 8.24 \\
\hline 10 & 100 & 0.25 & $30-40$ & 6.78125 & 10.34 \\
\hline 11 & 100 & 0.125 & $20-30$ & 6.98956 & 10.08 \\
\hline 12 & 150 & 0.025 & $20-30$ & 7.65375 & 9.81 \\
\hline 13 & 100 & 0.025 & $30-40$ & 6.9925 & 9.64 \\
\hline 14 & 100 & 0.125 & $20-30$ & 6.8956 & 9.9 \\
\hline 15 & 100 & 0.125 & $20-30$ & 6.7432 & 10.02 \\
\hline 16 & 100 & 0.025 & $5-7$ & 6.1875 & 8.83 \\
\hline 17 & 150 & 0.125 & $5-7$ & 7.35938 & 8.71 \\
\hline
\end{tabular}

\subsection{Interaction Effect of Three Factors on Biomass and $p H$}

Interactions can reflect synergy trends between factors [28,29]. Three-dimensional response plots (Figure $4 \mathrm{a}, \mathrm{c}, \mathrm{e}$ ) and two-dimensional contour plots (Figure $4 \mathrm{~b}, \mathrm{~d}, \mathrm{f}$ ) for biomass are shown in Figure 4 . The obvious difference is reflected in Figure $4 a, c, e$. From the surface plot of Figure $4 a$ (disturbance rate and solid-liquid ratio) and c (disturbance rate and particle size), the significance of the interaction is revealed by the obvious curved arch. In contrast, the combination of particle size and solid-liquid ratio appears to be weak according to Figure 4e. This comparison illustrates that the interaction of physical factors has a significant impact on the biomass of C. vulgaris. 
Specifically, Figure 4a portrays that to get the highest biomass $\left(7.4 \times 10^{6}\right.$ cells $\left./ \mathrm{mL}\right)$ under the interaction of disturbance rate and solid-liquid ratio, the values of control factors are obtained as $150 \mathrm{r} / \mathrm{min}$ disturbance rate, and $0.025 \mathrm{~g} / \mathrm{mL}$ solid-liquid ratio. In Figure $4 \mathrm{c}$, the maximum biomass is displayed under the condition of $120 \mathrm{r} / \mathrm{min}$ disturbance rate and 5-7 M particle size. Furthermore, it is obvious that the disturbance rate plays a more significant role. So, the disturbance rate has more influence on biomass than other factors. However, the 3D surface is close to a plane in Figure 4e and the two-dimensional contour plot does not form a curved arch in Figure 4f; this case indicates a weak response between particle size and solid-liquid ratio.
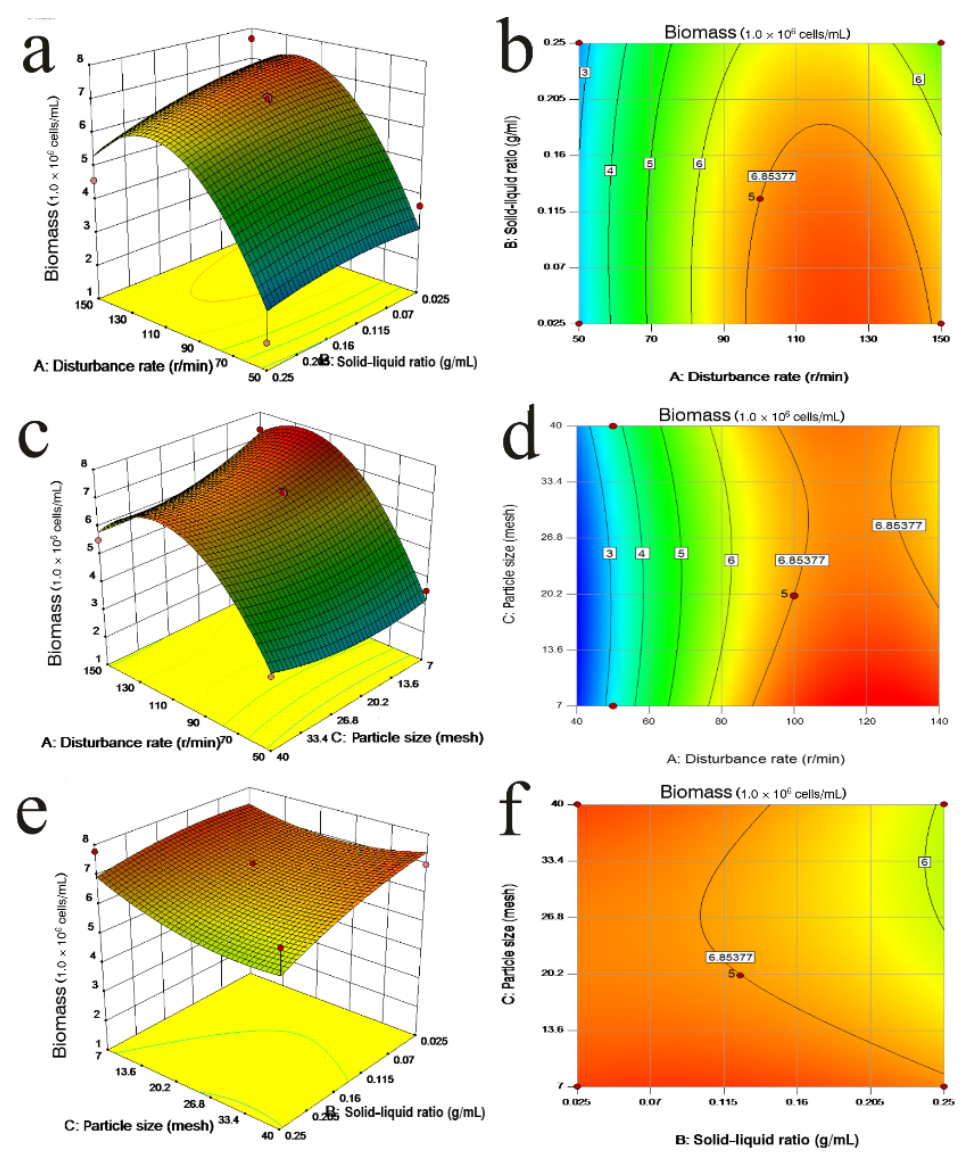

Figure 4. Three-dimensional response plots and two-dimensional contour plots for biomass: interactions of A (disturbance rate) and B (solid-liquid ratio) in (a,b); interactions of A (disturbance rate) and C (particle size) in (c,d); interactions of B (solid-liquid ratio) and C (particle size) in (e,f).

The cell reproduction of $C$. vulgaris can be affected by physical conditions. However, the effects of three factors on solution $\mathrm{pH}$ and biomass are not consistent in the orthogonal analysis, although the difference in mechanism is unknown. Since the value of solution $\mathrm{pH}$ is considered to be an important indicator of microalgae growth and water quality $[30,31]$, it is necessary to study the change of $\mathrm{pH}$.

Three-dimensional response plots and two-dimensional contour plots for $\mathrm{pH}$ are shown in Figure 5. Following analysis of the 3D surface, the effect of the interaction on the $\mathrm{pH}$ is obvious in Figure $5 \mathrm{a}, \mathrm{c}, \mathrm{e}$. Figure 5a shows that the $\mathrm{pH}$ increased with increasing the disturbance rate when the solid-liquid ratio reached the maximum value $(0.25 \mathrm{~g} / \mathrm{mL})$. Also, similar trends appear in Figure $5 \mathrm{c}, \mathrm{e}-$ the finer particle size (corresponding to a larger mesh) corresponds to the higher $\mathrm{pH}$. From the contour plots, Figure $5 \mathrm{f}$ presents an ellipse compared to $b$ and $d$. This explains that the interaction between particle size and solid-liquid ratio is very strong in response to solution $\mathrm{pH}$. 

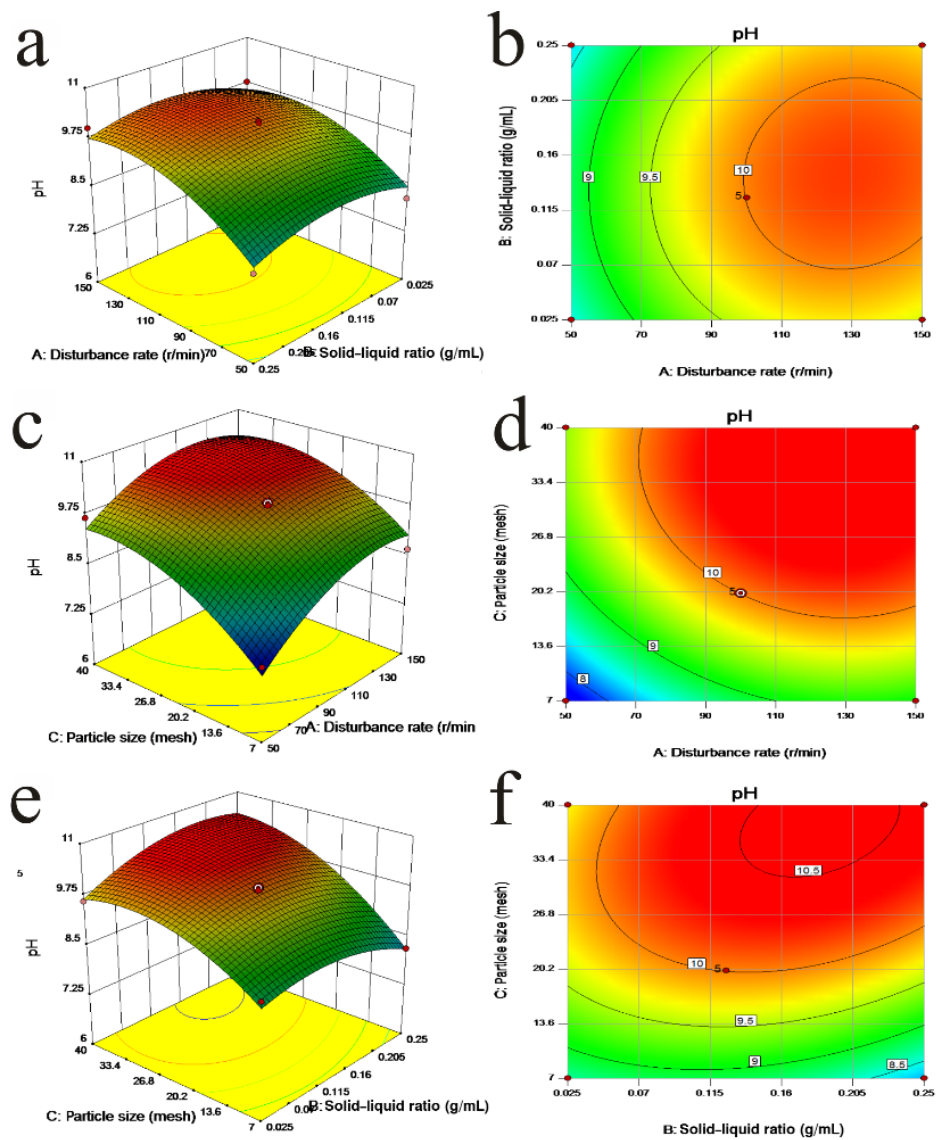

Figure 5. Three-dimensional response plots and two-dimensional contour plots for $\mathrm{pH}$ : interactions of $\mathrm{A}$ (disturbance rate) and B (solid-liquid ratio) in (a,b); means of the interactions of A (disturbance rate) and $C$ (particle size) in (c,d); interactions of B (solid-liquid ratio) and C (particle size) in (e,f).

Summarizing the above analysis, the interaction of physical factors has different effects on $\mathrm{pH}$ and biomass, although the $\mathrm{pH}$ of the solution is also affected by biomass production of the microalgae [32]. Therefore, the maximization of $\mathrm{pH}$ value and the biomass production of $C$. vulgaris can be adjusted by the optimization of the disturbance rate, the solid-liquid ratio and the particle size in the actual environment.

\subsection{Optimization of Biomass}

Optimum condition of biomass was determined by RSM within the variable range under study. Figure 6 displays the ramp desirability for the optimization of biomass $(\mathrm{D}=0.581)$. The optimum levels of three variables for the biomass of $C$. vulgaris are obtained as $105 \mathrm{r} / \mathrm{min}$ disturbance rate, $0.117 \mathrm{~g} / \mathrm{mL}$ solid-liquid ratio and $40 \mathrm{M}$ particle size. Meanwhile, the specific growth rate and solution $\mathrm{pH}$ under this condition will reach $0.27 / \mathrm{d}$ and 10.4 when the biomass is at a high level of $7.1 \times 10^{6} \mathrm{cells} / \mathrm{mL}$.

In Figure 1, the conditions of $100 \mathrm{r} / \mathrm{min}$ disturbance rate, $0.125 \mathrm{~g} / \mathrm{mL}$ solid-liquid ratio and $40 \mathrm{M}$ particle size are the closest to the optimized conditions, and the biomass of $7.0 \times 10^{6}$ cells $/ \mathrm{mL}$ is basically consistent with the optimized prediction, which reflects the accuracy of the model calculations. 


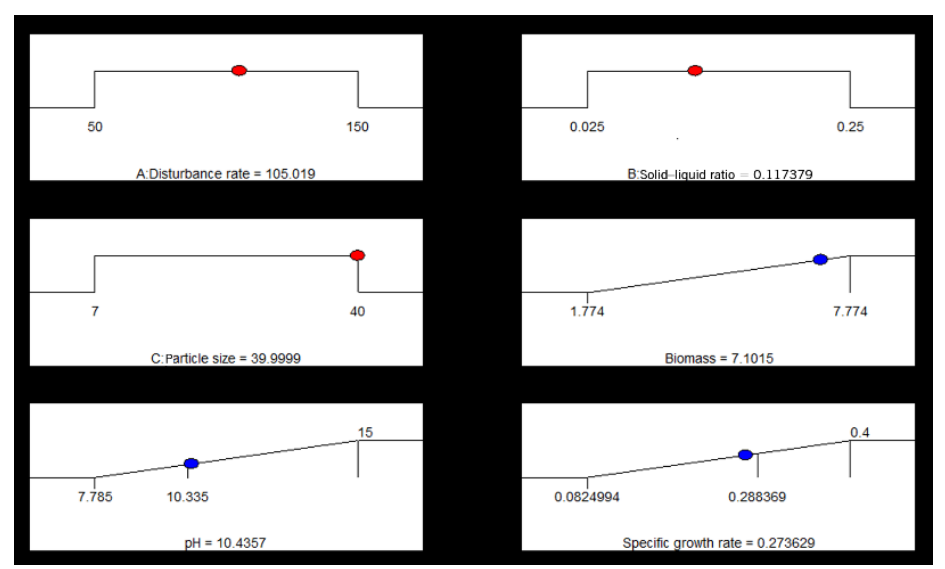

Figure 6. Ramp desirability for the optimization of biomass: the red circle represents the optimized value of the independent variable, the blue circle represents the optimized value of the dependent variable.

\section{Conclusions}

In this paper, the effects of disturbance rate, particle size and solid-liquid ratio in a sediment water system on the growth of $C$. vulgaris are systematically investigated. During the growth of C. vulgaris, the effects of different combinations of the three variables on biomass, solution $\mathrm{pH}$, and specific growth rate are different. Individual differences are reflected in the effect curve of a single factor. ANOVA displays significance of biomass with $F$-test in orthogonal analysis. The disturbance rate and particle size of the sediment are most significant; disturbance rate can largely determine the growth of $C$. vulgaris. The optimization calculation of biomass was carried out by RSM, and the results show that the biomass can reach $7.0 \times 10^{6}$ cells $/ \mathrm{mL}$ under a disturbance rate of $100 \mathrm{r} / \mathrm{min}$, a solid-liquid ratio of $0.125 \mathrm{~g} / \mathrm{mL}$ and a particle size of $40 \mathrm{M}$. However, further research needs to be carried out on mechanisms behind this. In addition, this study may be flawed in some details, such as a lack of information about how physical conditions affect nutrient absorption.

Author Contributions: Conceptualization, Y.C.; Formal analysis, J.L.; Investigation, S.C.; Writing-original draft, L.H.; Writing-review and editing, X.W.; Visualization, Q.L. X.W., Q.L. and L.H. conducted the experimental samples, collected and analyzed the data. Y.C. and S.C. supervised the research. J.L. provided important advice on the structures of the manuscript. In addition, X.W. strengthened the language of the manuscript. All authors have read and agreed to the published version of the manuscript.

Funding: This research was funded by the National Key Research and Development Plan of China, (grant no. 2016TFC0502204), the National Natural Science Foundation of China (grant no. 51809219) and the Open Research Fund Program of State Key Laboratory of Hydroscience and Engineering (sklhse-2019-B-02).

Acknowledgments: We would like to thank the Southwest University of Science and Technology for the experiment platform. The work was supervised and supported by Y.C., J.L. and S.C. We acknowledge X.W. for English language usage and quality. In addition, thanks to Q.L. for her guidance.

Conflicts of Interest: The authors declare no conflict of interest.

\section{References}

1. Chen, Z.; Song, S.; Wen, Y. Reduction of Cr (VI) into Cr (III) by organelles of Chlorella vulgaris in aqueous solution: An organelle-level attempt. Sci. Total. Environ. 2016, 572, 361-368. [CrossRef] [PubMed]

2. Tan, F.; Wang, Z.; Zhouyang, S.; Li, H.; Xie, Y.; Wang, Y.; Zheng, Y.; Li, Q. Nitrogen and phosphorus removal coupled with carbohydrate production by five microalgae cultures cultivated in biogas slurry. Bioresour. Technol. 2016, 221, 385-393. [CrossRef] [PubMed]

3. Tran, H.T.; Vu, N.D.; Matsukawa, M.; Okajima, M.; Kaneko, T.; Ohki, K.; Yoshikawa, S. Heavy metal biosorption from aqueous solutions by algae inhabiting rice paddies in Vietnam. J. Environ. Chem. Eng. 2016, 4, 2529-2535. [CrossRef] 
4. Lalhmunsiama; Gupta, P.L.; Jung, H.; Tiwari, D.; Kong, S.-H.; Lee, S.-M. Insight into the mechanism of $\mathrm{Cd}(\mathrm{II})$ and $\mathrm{Pb}(\mathrm{II})$ removal by sustainable magnetic biosorbent precursor to Chlorella vulgaris. J. Taiwan Inst. Chem. Eng. 2017, 71, 206-213. [CrossRef]

5. Chen, H.; Wang, J.; Zheng, Y.; Zhan, J.; He, C.; Wang, Q. Algal biofuel production coupled bioremediation of biomass power plant wastes based on Chlorella sp C2 cultivation. Appl. Energy 2018, 211, 296-305. [CrossRef]

6. Karmakar, R.; Rajor, A.; Kundu, K.; Kumar, N. Production of biodiesel from unused algal biomass in Punjab, India. Pet. Sci. 2018, 15, 164-175. [CrossRef]

7. Abdelnour, S.A.; Sheiha, A.M.; Taha, A.E.; Swelum, A.A.; Alarifi, S.; Alkahtani, S.; Ali, D.; AlBasher, G.; Almeer, R.; Falodah, F.; et al. Impacts of Enriching Growing Rabbit Diets with Chlorella vulgaris Microalgae on Growth, Blood Variables, Carcass Traits, Immunological and Antioxidant Indices. Animals 2019, 9, 788. [CrossRef]

8. Gopalakrishnan, K.; Roostaei, J.; Zhang, Y. Mixed culture of Chlorella sp. and wastewater wild algae for enhanced biomass and lipid accumulation in artificial wastewater medium. Front. Environ. Sci. Eng. 2018, 12, 14. [CrossRef]

9. Wang, X.; Lin, L.; Lu, H.; Liu, Z.; Duan, N.; Dong, T.; Xiao, H.; Li, B.; Xu, P. Microalgae cultivation and culture medium recycling by a two-stage cultivation system. Front. Environ. Sci. Eng. 2018, 12, 14. [CrossRef]

10. Song, Y.; Zhang, L.L.; Li, J.; Chen, M.; Zhang, Y.W. Mechanism of the influence of hydrodynamics on Microcystis aeruginosa, a dominant bloom species in reservoirs. Sci. Total. Environ. 2018, 636, 230-239. [CrossRef]

11. Xiao, Y.; Li, Z.; Li, C.; Zhang, Z.; Guo, J. Effect of Small-Scale Turbulence on the Physiology and Morphology of Two Bloom-Forming Cyanobacteria. PLoS ONE 2016, 11, e0168925. [CrossRef] [PubMed]

12. Yu, Q.; Chen, Y.; Liu, Z.; de Giesen, N.; Zhu, D. The Influence of a Eutrophic Lake to the River Downstream: Spatiotemporal Algal Composition Changes and the Driving Factors. Water 2015, 7, 2184-2201. [CrossRef]

13. Long, T.-Y.; Wu, L.; Meng, G.-H.; Guo, W.-H. Numerical simulation for impacts of hydrodynamic conditions on algae growth in Chongqing Section of Jialing River, China. Ecol. Model. 2011, 222, 112-119. [CrossRef]

14. Brito, A.; Newton, A.; Tett, P.; Fernandes, T.F. Sediment and water nutrients and microalgae in a coastal shallow lagoon, Ria Formosa (Portugal): Implications for the Water Framework Directive. J. Environ. Monit. 2010, 12, 318-328. [CrossRef] [PubMed]

15. Liu, G.F.; Shen, Q.S.; Zhang, L.; Fan, C.X.; Zhong, J.C.; Yan, S.H. [Environment effects of algae-caused black spots: Driving effects on the N, P changes in the water-sediment interface]. Huan Jing Ke Xue 2010, 31, 2917-2924.

16. Deng, Z.; He, Q.; Safar, Z.; Chassagne, C. The role of algae in fine sediment flocculation: In-situ and laboratory measurements. Mar. Geol. 2019, 413, 71-84. [CrossRef]

17. Yang, J.; Holbach, A.; Wilhelms, A.; Qin, Y.; Zheng, B.; Zou, H.; Qin, B.; Zhu, G.; Norra, S. Highly time-resolved analysis of seasonal water dynamics and algal kinetics based on in-situ multi-sensor-system monitoring data in Lake Taihu, China. Sci. Total. Environ. 2019, 660, 329-339. [CrossRef]

18. Li, Z.; Tang, H.; Xiao, Y.; Zhao, H.; Li, Q.; Ji, F. Factors influencing phosphorus adsorption onto sediment in a dynamic environment. J. Hydro-Environ. Res. 2016, 10, 1-11. [CrossRef]

19. Mayers, J.J.; Flynn, K.J.; Shields, R.J. Influence of the N:P supply ratio on biomass productivity and time-resolved changes in elemental and bulk biochemical composition of Nannochloropsis sp. Bioresour. Technol. 2014, 169, 588-595. [CrossRef]

20. Safi, C.; Zebib, B.; Merah, O.; Pontalier, P.-Y.; Vaca-Garcia, C. Morphology, composition, production, processing and applications of Chlorella vulgaris: A review. Renew. Sustain. Energy Rev. 2014, 35, 265-278. [CrossRef]

21. Sharma, A.; Arya, S.K. Hydrogen from algal biomass: A review of production process. Biotechnol. Rep. 2017, 15, 63-69. [CrossRef] [PubMed]

22. Sun, R.; Sun, P.; Zhang, J.; Esquivel-Elizondo, S.; Wu, Y. Microorganisms-based methods for harmful algal blooms control: A review. Bioresour. Technol. 2018, 248, 12-20. [CrossRef]

23. Iman Shayan, S.; Agblevor, F.A.; Bertin, L.; Sims, R.C. Hydraulic retention time effects on wastewater nutrient removal and bioproduct production via rotating algal biofilm reactor. Bioresour. Technol. 2016, 211, 527-533. [CrossRef] [PubMed] 
24. Wu, Z.; Zhu, Y.; Huang, W.; Zhang, C.; Li, T.; Zhang, Y.; Li, A. Evaluation of flocculation induced by pH increase for harvesting microalgae and reuse of flocculated medium. Bioresour. Technol. 2012, 110, 496-502. [CrossRef] [PubMed]

25. Alyabyev, A.; Andreyeva, I.; Rachimova, G. Influence of $\mathrm{pH}$ shift and salting on the energetics of microalgae Chlorella vulgaris and Dunaliella maritima. J. Therm. Anal. Calorim. 2011, 104, 201-207. [CrossRef]

26. Khalil, Z.I.; Asker, M.M.S.; El-Sayed, S.; Kobbia, I.A. Effect of pH on growth and biochemical responses of Dunaliella bardawil and Chlorella ellipsoidea. World J. Microbiol. Biotechnol. 2010, 26, 1225-1231. [CrossRef] [PubMed]

27. Ashok, K.S.; Yadav, S.; Saminathan, K.R.; Monisha, N.; Malarvizhi, J.; Ganesan, M.; Mantri, V.A. An orthogonal design to optimize seed production, out-planting, and cultivation of the industrially overexploited red alga Gracilaria edulis (Rhodophyta). J. Appl. Phycol. 2016, 28, 1215-1223. [CrossRef]

28. Patil, P.D.; Gude, V.G.; Mannarswamy, A.; Cooke, P.; Munson-McGee, S.; Nirmalakhandan, N.; Lammers, P.; Deng, S. Optimization of microwave-assisted transesterification of dry algal biomass using response surface methodology. Bioresour. Technol. 2011, 102, 1399-1405. [CrossRef]

29. Kim, D.G.; Hong, C.-H.; Choi, Y.-E. Efficient algal biodiesel production with an optimal harvest condition obtained via response surface methodology. Bioresour. Technol. Rep. 2019, 7, 100213. [CrossRef]

30. Liang, Z.J.; Liu, Y.; Ge, F.; Liu, N.; Wong, M.H. A pH-dependent enhancement effect of co-cultured Bacillus licheniformis on nutrient removal by Chlorella vulgaris. Ecol. Eng. 2015, 75, 258-263. [CrossRef]

31. Yang, F.F.; Xiang, W.Z.; Fan, J.W.; Wu, H.L.; Li, T.; Long, L.J. High pH-induced flocculation of marine Chlorella sp for biofuel production. J. Appl. Phycol. 2016, 28, 747-756. [CrossRef]

32. Gong, Q.T.; Feng, Y.Z.; Kang, L.G.; Luo, M.Y.; Yang, J.H. Effects of light and pH on cell density of Chlorella vulgaris. Energy Procedia 2014, 61, 2012-2015. [CrossRef]

(C) 2019 by the authors. Licensee MDPI, Basel, Switzerland. This article is an open access article distributed under the terms and conditions of the Creative Commons Attribution (CC BY) license (http://creativecommons.org/licenses/by/4.0/). 